\title{
不同林龄杉木组织迁移养分的再利用
}

\author{
吕中诚 康文星 $^{1,2,3^{*}}$ 黄志宏 $1,2,3$ 赵仲辉 ${ }^{1,2,3}$ 邓湘雯 $1,2,3$
}

${ }^{1}$ 中南林业科技大学, 长沙 410004; ${ }^{2}$ 南方林业生态应用技术国家工程实验室, 长沙 410004; ${ }^{3}$ 湖南会同杉木林国家重点野外科学观测研究站, 湖南会 同 418307; 湖南警察学院, 长沙 410138

摘 要 为了清楚了解不同林龄杉木(Cunninghamia lanceolata)组织迁移养分(氮、磷、钾、钲、镁)再利用特征, 为人工林丰 产的经营管理提供科学依据，该文利用湖南会同杉木林不同林龄段的活的枝叶与枯死枝叶养分浓度及其差异和枝叶枯死量， 估算枝叶枯死前的养分迁移量。用某林龄段开始和结束时的杉木器官的养分浓度差异, 估算那些在某林龄段开始前林分生产 的, 在林龄段结束时仍存活的器官(干、皮、枝、叶、根), 即仍存活物质, 在该林龄段的养分迁移量。将枝叶枯死前迁移的养 分和这些仍存活物质中转移的养分与从土壤中吸收的养分相结合, 根据森林生产的生物量, 综合分析森林物质生产的养分利 用特征。研究表明: 1-7年生林分, 利用枝叶枯死前迁移的养分生产的生物量及占总生产生物量的比例, 分别为 $217 \mathrm{~kg} \cdot \mathrm{hm}{ }^{-2} \cdot \mathrm{a}^{-1}$ 和 $3.52 \% ; 20-25$ 年生林分则分别上升到 $2540 \mathrm{~kg} \cdot \mathrm{hm}^{-2} \cdot \mathrm{a}^{-1}$ 和 $17.50 \%$ 。枝叶枯死前迁移的养分生产的生物量及占总生产生物量的 比例都随林龄增加而增大。林分在12-16、17-20、21-25年林龄段, 由这些仍存活物质中迁移出的养分生产的生物量分别为 385、561和 $450 \mathrm{~kg} \cdot \mathrm{hm}^{-2} \cdot \mathrm{a}^{-1}$, 分别占总生产生物量的 $3.40 \% 、 3.40 \%$ 和 $3.11 \%$ 。这些仍存活物质中迁移出的养分量随林龄增加呈 现先上升后下降的变化, 由这些养分生产的物质量占总生产物质量的比例随林龄增加呈下降趋势。结果显示, 只要有枝叶枯 死发生, 就有枝叶枯死前迁移出养分用于物质再生产。林分郁闭后, 才会发生这些仍存活物质中迁移出的养分再利用。杉木 体内养分再分配及咜备机制、杉木生长规律和不同生长发育阶段对养分的需求和利用效率等, 共同调节控制着枝叶枯死前迁 移的和这些仍存活物质中迁移出的养分再利用的年变化。

关键词 杉木; 人工林; 养分迁移; 养分再利用; 物质生产

吕中诚, 康文星, 黄志宏, 赵仲辉, 邓湘雯 (2019). 不同林龄杉木组织迁移养分的再利用. 植物生态学报, 43, 458-470. DOI: 10.17521/cjpe.2018.0212

\section{Reuse of retranslocated nutrients in tissues of Chinese fir in plantations of different ages}

LÜ Zhong-Cheng ${ }^{1,4}$, KANG Wen-Xing ${ }^{1,2,3^{*}}$, HUANG Zhi-Hong ${ }^{1,2,3}$, ZHAO Zhong-Hui ${ }^{1,2,3}$, and DENG Xiang-Wen ${ }^{1,2,3}$

${ }^{1}$ Central South University of Forestry and Technology, Changsha 410004, China; ${ }^{2}$ National Engineering Laboratory for Applied Technology of Forestry \& Ecology in South China, Changsha 410004, China; ${ }^{3}$ Huitong National Field Station for Scientific Observation and Research of Chinese Fir Plantation Ecosystem, Huitong, Hunan 418307, China; and ${ }^{4}$ Hunan Police College, Changsha 410138, China

\section{Abstract}

Aims The purpose of this study is to investigate the reuse characteristics of nutrients (Nitrogen, Phosphorus, Potassium, Calcium, Magnesium) in Cunninghamia lanceolata with different ages, and therefore provide scientific support for better management of the high-yield plantations in China.

Methods We estimated the nutrient retranslocation from dying branches and leaves according to nutrient concentration differences between living and dead, and the amount of dead branches and leaves in Chinese fir forests of different age classes in Hunan Huitong. Based on the difference in the nutrient concentrations of Chinese fir organs at the beginning and end of each age class, the nutrient transport amount from "biomass produced before the beginning of a given age class, which is still alive at the end of the age class" (referred as "biomass-still-alive" hereafter) was estimated for the age class. The nutrient utilization characteristics in forest production were comprehensively analyzed by combining the nutrients transferred from dying branches and leaves with those transferred from the biomass still alive and absorbed from the soil.

Important findings The results showed that the annual biomass produced by the retranslocated nutrients of dying branches and leaves and their proportion in the total biomass were $217 \mathrm{~kg} \cdot \mathrm{hm}^{-2} \cdot \mathrm{a}^{-1}$ and $3.52 \%$, respectively, for forests 1-7 years old, and increased to $2540 \mathrm{~kg} \cdot \mathrm{hm}^{-2} \cdot \mathrm{a}^{-1}$ and $17.50 \%$, respectively, when forests reached

收稿日期Received: 2018-08-27 接受日期Accepted: 2019-04-02

基金项目：国家林业公益性行业科研专项(201104009)、科技部公益性研究项目(2007-04-15)和国家野外科学观测研究站项目(20080615)。Supported by the National Forestry Public Welfare Industry Research Project (201104009), the Ministry of Science and Technology Public Welfare Research Project (2007-04-15), and the National Field Science Observation and Research Station Project (20080615).

* 通信作者Corresponding author (kwx1218@126.com) 
20-25 years old. The biomass produced by the retranslocated nutrients of dying branches and leaves and its proportion in the total biomass increased with the increase of forest age. The average annual biomass produced by the biomass-still-alive in stands of 12-16, 17-20 and 21-25 years old was 385,561 and $450 \mathrm{~kg} \cdot \mathrm{hm}^{-2} \cdot \mathrm{a}^{-1}$, accounting for $3.40 \%, 3.40 \%$ and $3.11 \%$ of the total biomass production, respectively. The nutrient retranslocation from the biomass-still-alive first increased and then decreased with the increase of forest age, and the proportion of the biomass produced by these nutrients to the total biomass showed a decreasing trend with the increase of forest age. The results show that the death of branches and leaves always results in reuse of retranslocated nutrients. On the other hand, the reuse of retranslocated nutrients from the biomass-still-alive occurs only after canopy closure. The mechanism of nutrient redistribution and storage, the growth pattern and the nutrient demand and utilization efficiency at different growth stages of Chinese fir jointly regulate and control the annual changes of nutrient retranslocation before branches and leaves die and the reuse of retranslocated nutrients from the biomass-still-alive.

Key words Cunninghamia lanceolata; plantation; retranslocated nutrients; reuse of nutrients; biomass production

Lü ZC, Kang WX, Huang ZH, Zhao ZH, Deng XW (2019). Reuse of retranslocated nutrients in tissues of Chinese fir in plantations of different ages. Chinese Journal of Plant Ecology, 43, 458-470. DOI: 10.17521/cjpe.2018.0212

林分的养分主要被用于物质生产 (吴鹏飞和马 祥庆, 2009; 李钦禄等, 2015), 因而养分利用成为森 林生态系统生产力和养分循环研究的重要环节。20 世纪 80 年代以来, 我国学者将林分养分动态与生物 量相结合开展了杉木(Cunninghamia lanceolata)(刘 爱琴等, 2005; 田大伦等, 2011)、湿地松(Pinus elliottii)(肖兴翠等, 2013)、马占相思 (Acacia mangium)(何斌等, 2007)、尾叶桉(Eucalyptus grandis $\times$ E. urophylla)(林德喜等, 2002)、马尾松(Pinus massoniana)(项文化和田大伦, 2002)、橡胶树(Hevea brasiliensis)(曹建华等, 2010)等人工林的养分利用研究, 这些研究成果具有重要的理论和实践意义。以往研 究林分生产物质利用的养分都用“吸收=存留+归 还”方法求算，这种估算忽略了植物组织迁移养分 的再利用(Killingbeck, 1986; Aerts, 1990; Chen \& Brassard, 2013)。植物组织迁移的养分在新的物质生 产中再利用, 不仅提高了养分的利用效率, 促进了 林分养分的循环(Mayor et al., 2013), 而且减少了植 物对土壤养分的吸收, 维护了林地地力, 降低了植 物对环境的依赖性(Shaver \& Melillo, 1984; Lim \& Cousens, 1986), 对森林生态系统的养分循环、植物 种群和群落稳定性都具有重要的生态学意义。然而 目前对植物组织内的养分迁移与利用研究, 几乎全 部集中在不同生活型植物(曾琦等, 2008; 张立华等, 2009; 宗宁等, 2017), 不同林龄植物 (曾德慧等, 2005; Ye, 2012; 邓浩俊等, 2015; 林宝平等, 2017)衰 老组织养分转移率的差异; 以及海拔 (郑媛等, 2017)、土壤肥力(赵琼等, 2010; 安卓等, 2011)对植 物组织衰老时养分转移的影响上, 很少探讨植物衰 老组织转移的养分在林分新的物质生产中的再利
用。虽然在 20 世纪 50 年代已发现草本植物活组织内 养分的循环和再分配现象(Williams, 1955), 发现植 物活组织迁移出的养分可活化用以补充(至少部分 地补充)物质生产中所需养分(Miller, 1984，1986), 但由于研究方法(同位素追踪技术)成本高且不安全, 因此, 鲜见对乔木活组织的养分迁移与再利用的报 道。如果仅用从土壤中吸收的养分, 忽略植物组织 迁移养分的再利用, 就不能真实地反映植物养分利 用特征, 也不能完全揭示植物养分利用的机理。本 研究利用湖南会同杉木林生态系统国家野外科学观 测研究站连续25年定位测定的生物量和林木养分含 量数据, 定量估算了不同林龄段杉木枝叶枯死前向 活体组织转移的养分量, 并估算了“那些在某林龄 段开始前林分生产的, 在这林龄段结束时仍存活的 器官(干、皮、枝、叶、根)”(“”内文字后文中用“仍 存活物质”表示) 中, 在这林龄段内的养分迁移量。 将这些养分与从土壤吸收的养分结合一起, 综合分 析林分物质生产的养分利用特征, 旨在揭示树木组 织的迁移养分再利用策略, 为人工林的经营管理提 供科学依据。

\section{1 材料和方法}

\section{1 研究区域概况}

本研究所选林分位于湖南会同杉木林生态系统 国家野外科学观测研究站第3集水区试验林内。1987 年冬采伐了该集水区第1代杉木林。1988年春在采伐 迹地炼山、全垦挖穴营造第2代杉木林, 造林密度 2200 株 $\cdot \mathrm{hm}^{-2}$ 。前 3 年(包括造林当年)的春、秋季各 抚育 1 次, 以后任其自然生长。研究林分的地理位置 为 $26.83^{\circ} \mathrm{N}, 109.75^{\circ} \mathrm{E}$, 坡向西北, 坡度 $15^{\circ}-25^{\circ}$, 海 
拔270-350 m。研究区年降水量1 100-1 $400 \mathrm{~mm}$, 年 平均气温 $16.9{ }^{\circ} \mathrm{C}$, 属于中亚热带季风湿润气候区。 土壤为板页岩发育的黄壤, 风化程度较深, 土层厚 度超过 $80 \mathrm{~cm}$ 。

\section{2 林分观测样地设置}

湖南会同杉木林生态系统国家野外科学观测研 究站为了研究杉木林生态系统的结构功能, 1994年 在第3集水区山坡中上部和中下部的7年生第 2 代杉 木林内各设 2 块(共4块) $20 \mathrm{~m} \times 33.33 \mathrm{~m}$ 长方形样地 进行各项观测试验。

\section{3 生物量测定}

在林龄为 $7 、 11 、 16 、 20 、 25$ 年时 $($ 与第 1 代林测 定生物量的林龄相同), 在4块观测样地测定林分生 物量。生物量测定采用克拉夫特的林木生长状况分 级法(林业部科技司, 1994), 把样地内所有林木分成 优势木(I级木)、亚优势木(II级木)、中级木(III级木)、 被压木(IV级木)、濒死木(V级木) 5 个生长等级, 测 定样地内每株树木的树高、胸径和冠幅。根据样地 所有树木平均树高和胸径选取样地标准木 1 株, 根 据各生长级树木的平均树高和胸径选取各生长级标 准木 1 株(样地中总计 6 株样木), 将它们连根挖出。在 现场将树干按 $2 \mathrm{~m}$ 分区段, 测定各区段树干、皮、枝 和叶的生物量鲜质量, 并测定根的鲜质量。选取杉 木各器官样品, 称量后放在 $80{ }^{\circ} \mathrm{C}$ 的烘箱内烘干至 恒质量。求出样品的含水率, 将各器官鲜质量换算 成干质量。根据相对生长法则建立生物量估算模型, 再用经过检验的模型估算单位面积林分生物量。

\section{4 枝叶枯死量估算}

根据杉木枝、叶生长周期(寿命)估算不同林龄 时林分枝叶枯死量。杉木叶片生长周期定为 5 年(刘 爱琴等, 2005), 杉木树枝生长周期定为 10 年(根据在 会同长期观测的结果)。用下式估算单位面积林分不 同林龄时的枝、叶枯死量。

$$
\begin{aligned}
& W_{1 t}=W_{1(t-5)} \\
& W_{2 t}=W_{2(t-10)}
\end{aligned}
$$

式中, $W_{1 t}$ 表示单位面积林分 $t$ 年生时的叶枯死量; $W_{2 t}$ 表示单位面积林分 $t$ 年生时的枝枯死量; $W_{1(t-5)}$ 表示 单位面积林分 $(t-5)$ 年生时生产的叶量; $W_{2(t-10)}$ 表 示单位面积林分 $(t-10)$ 年生时生产的枝量。

\section{5 分析样品采集}

每次测定生物量的同时采集分析样品。为了保 证样品具有代表性, 将每次生物量测定的伐倒木分
成树干基部、中下、中、中上和上部 5 个区段，根据 每一区段树干质量的权重比分区段采集树干样品, 再把各区段采集的树干样品混合在一起组合成树干 样品。树皮取样采用与树干相同的方法。枝和叶都 分成当年生、一年生、二年生、多年生分别取样。 将根分成根头、大根(直径 $\geqslant 1 \mathrm{~cm}$ )、粗根(直径 $0.2-$ $1.0 \mathrm{~cm}$ )、细根 $($ 直径 $<0.2 \mathrm{~cm}$ ) 分别取样。同时从活树 上收集刚枯死枝叶样品。

\section{6 养分测定}

取适量待测的样品置 $85{ }^{\circ} \mathrm{C}$ 恒温干燥箱内烘干 至恒质量, 称质量并磨碎, 过 60 目篮，按《森林生态 系统研究方法》(林业部科技司, 1994)中的养分测定 方法配置待测溶液。全钾 $(\mathrm{TK})$ 、全钙 $(\mathrm{TCa}) 、$ 全镁 $(\mathrm{TMg})$ 含量用原子吸收分光光度计测定, 全磷(TP) 含量用分光光度计测定, 全氮(TN)含量用半微量凯 氏法测定。每个样品重复测定 3 次, 用 3 次重复测定 的平均值作为计量标准。

\section{7 不同林龄段林分生产的生物量估算}

单位面积林分某林龄段生产的树干、树皮生物 量, 根据生长过程中树干、树皮调落甚少的规律, 用 某林龄段开始和结束时单位面积林分测定的这些器 官现存量之差求得。根系存在更新代谢过程, 但要 准确测定根系(尤其是细根)的生长周期, 需采用微 根管技术或同位素追踪技术。这些技术方法成本高 且操作有一定的难度, 因而大多数研究者在估算某 林龄段根生产量时，将根与干材和树皮同等对待 (梅莉等, 2004; 王端丽等, 2012)。本研究也是如此 (这样估算出的根生产量要低于它的实际生产量)。 杉木是常绿树种, 枝、叶都有一定的生长周期, 根据 陈日升等(2018)的研究方法, 估算出某林龄段这些 还存活的枝叶量。然后用下式估算某林龄段单位面 积林分生产的生物量 $(W)$ 。

$$
W=\left(W_{2 k}-W_{1 k}\right)+W_{3 k}+\left(W_{2 i}-W_{1 i}\right)
$$

式中, $W_{2 k}$ 表示某林龄段结束时的单位面积林分枝叶 现存量; $W_{1 k}$ 表示某林龄段“这些还存活的枝叶量”; $W_{3 k}$ 表示单位面积林分在某林龄段生长的枝叶在该 林龄段的枯死量; $W_{2 i} 、 W_{1 i}$ 分别表示某林龄段结束和 开始时单位面积林分的树干、树皮和根现存量; $k=$ 1,2 (枝、叶) $; i=1,2,3$ (干、皮、根)。

\section{8 不同林龄段杉木活组织的养分转移量计算}

根据某林龄段结束时的杉木各器官养分浓度 $\left(L_{2 p}\right)$ 和开始时的浓度 $\left(L_{1 p}\right)$, 以及这林龄段“仍存活物 
质” $\left(W_{m p}\right)$, 估算单位面积“仍存活物质”在这林龄段 的养分转移量。若 $L_{2 p}<L_{1 p}$, 表示这林龄段“仍存活 物质”有部分养分被转移出来, 转移量 $(M)$ 为:

$$
M=W_{m p} \times\left(L_{2 p}-L_{1 p}\right)
$$

若 $L_{2 p}>L_{1 p}$, 表示着这林龄段“仍存活物质”的 养分增加了, 有新的养分补充到“仍存活物质”内, 转移到“仍存活物质”的养分量是:

$$
M=W_{m p} \times\left(L_{1 p}-L_{2 p}\right)
$$
式中, $p=1,2,3,4,5$ (干、皮、枝、叶、根)。

\section{9 不同林龄段枝、叶枯死前养分转移量估算}

采用某林龄段枝叶枯死前养分浓度 $\left(L_{k m}\right)$ 与枯死 后养分浓度 $\left(L_{k n}\right)$ 之差, 以及在某林龄段单位面积林 分的枝叶枯死量 $\left(W_{3 k}\right)$, 用下式计算某林龄段单位面 积林分枝叶枯死前的养分转移量 $\left(M_{3}\right)$ 。

$$
M_{3}=W_{3 k} \times\left(L_{k m}-L_{k n}\right)
$$

\subsection{0 不同林龄段土壤养分吸收量估算}

单位面积林分不同林龄段土壤养分吸收量根据 陈日升等(2018)的方法估算。该方法考虑了枝叶枯 死前迁移的养分, 以及“仍存活物质”迁移养分的再 利用。在估算出单位面积林分某林龄段生产的生物 量(公式(3)) 和某林龄段 “仍存活物质”迁移出(或又 吸收)养分量(公式(4)和公式(5)), 以及单位面积林 分枝叶枯死前养分转移量(公式(6))后, 如果某林龄 段结束时杉木各器官养分浓度低于开始时, 则某林 龄段单位面积林分“仍存活物质”有部分养分迁移出 来, 可用于林分物质生产, 从而减少了土壤养分的 吸收量 $\left(M_{4}\right)$ 。其土壤养分吸收量用下面公式求得:

$$
\begin{aligned}
M_{4}= & L_{k m}\left(W_{2 k}-W_{1 k}\right)+W_{3 k} \times L_{k n}+ \\
& L_{p}\left(W_{2 i}-W_{1 i}\right)-M_{1}-M_{3}
\end{aligned}
$$

式中, $L_{p}$ 为某林龄段树干、皮和根的养分浓度; $M_{1}$ 为某林龄段单位面积林分 “仍存活物质”迁移出的养 分量; $p=1,2,3$ (干、皮、根)。

当某林龄段结束时杉木各器官养分浓度高于开 始时，表示某林龄段“仍存活物质”的养分增加了, 因此，该林龄段林分从土壤吸收的养分不仅用于本 林龄段林分的物质生产, 还有一些要输送到“仍存 活物质” 内, 这就增加了土壤养分的吸收量。其计算 公式为:

$$
\begin{aligned}
M_{4}= & L_{k m}\left(W_{2 k}-W_{1 k}\right)+W_{3 k} \times L_{k n}+ \\
& L_{p}\left(W_{2 i}-W_{1 i}\right)+M_{2}-M_{3}
\end{aligned}
$$

式中, $M_{2}$ 为某林龄段单位面积林分补充到“仍存活 物质”的养分量。

\subsection{1 不同林龄段林分养分利用效率估算}

不同林龄段林分的养分利用效率根据下面公式 计算:

$$
N=\left(M_{4}+M_{3}+M_{2}\right) / W
$$

式中, $N$ 表示养分的利用效率; $M_{4}$ 表示某林龄段单位 面积林分用于物质生产的土壤养分量; $M_{3}$ 表示某林 龄单位面积林分枝叶枯死前迁移养分的再利用量; $M_{2}$ 表示某林龄段单位面积林分“仍存活物质”迁移 养分的再利用量; $W$ 表示某林龄段单位面积林分生 产的生物量。

\subsection{2 数据分析处理}

所有数据经Excel软件处理, 用SPSS 20.0 软件 进行统计分析。采用最小显著差异 $(L S D)$ 法对林分吸 收的土壤养分量, 从活立木组织迁移的养分量, 枝 叶调落前迁移的养分量进行显著性检验，显著水平 为 $\alpha=0.05$ 。

\section{2 结果和分析}

\section{1 不同林龄段林分的生产力}

从图1看出, 同一林龄段杉木各器官生产力不 同，其中树干生产力最大。杉木是用材(干材利用) 树种, 这种特性决定了树干生产力是构成林分生产 力的主要部分。从图1中不同林龄段的杉木各器官生 产力的对比分析看出, 同一林龄段不同器官生产力 不同, 不同林龄段同一器官生产力也不一样, 这是 杉木自身的生长规律引起的。如杉木在快速生长阶 段(8-11年), 各器官生长速率都较大, 因而各器官 生产力之间的差别较其他林龄段更为均衡; 又如干 材积累阶段(17-20年), 杉木树干长粗, 干材积累增 大, 因此此林龄段树干生产力增大速率大于其他器 官。

林分在1-20年内其生产力持续增加, 20 年后生 产力下降。各器官生产力随林龄的变化是: 干、叶 的变化与林分生产力一样; 枝的生产力在1-11年时 上升、12-16年时下降、17-20年时上升、21-25年时 下降; 皮和根的生产力在1-11年时上升，12-16年时 下降, 17-25年时又上升。

\section{2 不同林龄段杉木活组织内的养分迁移量}

因为造林的苗木为一年生苗木，其苗木生物量 在7年生林分生物量中所占比例非常少, 可认为林 分7年生时测定的生物量，即是林分从造林那年到 第7年林分生产的生物量。那么7年生的林分就不存 
在这个林龄阶段的“仍存活物质”。所以表 1 和表 2 中 8 年后的各林龄段才有“仍存活物质”养分迁移数据。

从表1看出，8-11年生的林分，“仍存活物质”新 补充的养分为 $7.83 \mathrm{~kg} \cdot \mathrm{hm}^{-2} \cdot \mathrm{a}^{-1}$, 其中, $\mathrm{N} 、 \mathrm{P} 、 \mathrm{~K} 、 \mathrm{Ca} 、$ $\mathrm{Mg}$ 的平均补充量分别为 $3.11 、 0.37 、 1.36 、 1.96$ 和 1.03 $\mathrm{kg} \cdot \mathrm{hm}^{-2} \cdot \mathrm{a}^{-1}$ 。12年以后各林龄段“仍存活物质”平均
每年迁移出的养分为5.18-6.75 $\mathrm{kg} \cdot \mathrm{hm}^{-2}$, 其中, $\mathrm{N}$ 、 $\mathrm{P} 、 \mathrm{~K} 、 \mathrm{Ca} 、 \mathrm{Mg}$ 迁移量分别为 $1.30-1.66 、 0.40-0.53$ 、 $1.06-1.40 、 1.77-2.26 、 0.65-0.90 \mathrm{~kg} \cdot \mathrm{hm}^{-2} \cdot \mathrm{a}^{-1}$ 。从“仍 存活物质”迁移出的各养分量在12-20年内都呈上升 趋势, 20-25年内都呈下降趋势。

由表2可知，8-11年生的林分补充到“仍存活物

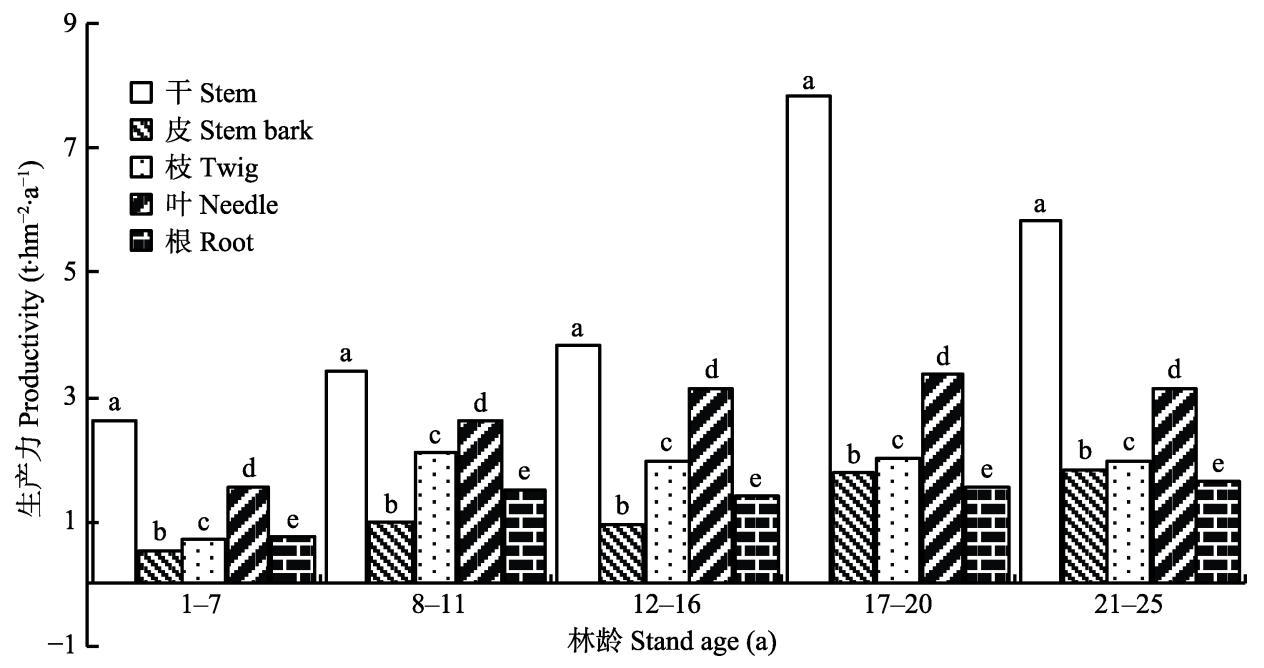

图1 不同林龄段杉木林的生产力。同一林龄时, 不同小写字母表示器官间差异显著 $(p<0.05)$ 。

Fig. 1 Productivity of Chinese fir forests in different age classes. In the same age, the different lowercase letters indicate significant differences among organs $(p<0.05)$.

表1 不同林龄杉木体内的养分元素迁移量

Table 1 Average annual nutrient element transfer within the body of Chinese fir in different ages

\begin{tabular}{|c|c|c|c|c|c|c|}
\hline \multirow{2}{*}{$\begin{array}{l}\text { 林龄 } \\
\text { Stand age (a) }\end{array}$} & \multicolumn{5}{|c|}{ 养分元素 Nutrient elements $\left(\mathrm{kg} \cdot \mathrm{hm}^{-2} \cdot \mathrm{a}^{-1}\right)$} & \multirow{2}{*}{$\begin{array}{c}\text { 合计 } \\
\text { Total }\left(\mathrm{kg} \cdot \mathrm{hm}^{-2} \cdot \mathrm{a}^{-1}\right)\end{array}$} \\
\hline & 氮 Nitrogen & 磷 Phosphorus & 钾 Potassium & 钙 Calcium & 镁 Magnesium & \\
\hline $8-11$ & $+3.11^{\mathrm{aM}}$ & $+0.37^{\mathrm{bM}}$ & $+1.36^{\mathrm{cM}}$ & $+1.96^{\mathrm{dM}}$ & $+1.03^{\mathrm{eM}}$ & $+7.83^{\mathrm{M}}$ \\
\hline $12-16$ & $-1.41^{\mathrm{aN}}$ & $-0.43^{\mathrm{bN}}$ & $-1.27^{\mathrm{cN}}$ & $-1.90^{\mathrm{dM}}$ & $-0.82^{\mathrm{eN}}$ & $-5.83^{\mathrm{N}}$ \\
\hline $17-20$ & $-1.66^{\mathrm{aR}}$ & $-0.53^{\mathrm{bR}}$ & $-1.40^{\mathrm{cM}}$ & $-2.26^{\mathrm{dR}}$ & $-0.90^{\mathrm{eR}}$ & $-6.75^{\mathrm{R}}$ \\
\hline $21-25$ & $-1.30^{\mathrm{aS}}$ & $-0.40 b^{\mathrm{N}}$ & $-1.06^{\mathrm{cS}}$ & $-1.77^{\mathrm{dS}}$ & $-0.65^{\mathrm{eS}}$ & $-5.18^{\mathrm{S}}$ \\
\hline
\end{tabular}

“-”, 以前生育阶段生长的植物体内养分中输送到这一生育阶段新生长生物量中的养分; “+”, 这一生育阶段新吸收的养分中流向以前生育阶段现存生 物体内的养分。同一行相同小写字母表示差异不显著 $(p>0.05)$; 同一列相同大写字母表示差异不显著 $(p>0.05)$ 。

"-", the nutrient was transported from individuals at the previous stage to the new growth biomass at this stage; "+", the newly absorbed nutrients in this growth stage flew to the nutrients of the existing organisms in the previous stage. The same row in the same lowercase letters that the difference is not significant $(p>$ $0.05)$. A certain age in the same column in the same uppercase letter that the difference is not significant $(p>0.05)$,

表2 不同林龄杉木器官的养分迁移量

Table 2 Average annual nutrient transfer in organs of Chinese fir in different ages

\begin{tabular}{lccccc}
\hline $\begin{array}{l}\text { 林龄 } \\
\text { Stand age (a) }\end{array}$ & $\begin{array}{c}\text { 干 Stem wood } \\
\left(\mathrm{kg} \cdot \mathrm{hm}^{-2} \cdot \mathrm{a}^{-1}\right)\end{array}$ & $\begin{array}{c}\text { 皮 Stem bark } \\
\left(\mathrm{kg} \cdot \mathrm{hm}^{-2} \cdot \mathrm{a}^{-1}\right)\end{array}$ & $\begin{array}{c}\text { 枝 Twig } \\
\left(\mathrm{kg} \cdot \mathrm{hm}^{-2} \cdot \mathrm{a}^{-1}\right)\end{array}$ & $\begin{array}{c}\text { 叶 Needle } \\
\left(\mathrm{kg} \cdot \mathrm{hm}^{-2} \cdot \mathrm{a}^{-1}\right)\end{array}$ & $\begin{array}{c}\text { 根 Root } \\
\left(\mathrm{kg} \cdot \mathrm{hm}^{-2} \cdot \mathrm{a}^{-1}\right)\end{array}$ \\
\hline $8-11$ & $+1.01^{\mathrm{aM}}$ & $+1.21^{\mathrm{bM}}$ & $+2.10^{\mathrm{cM}}$ & $+2.92^{\mathrm{dM}}$ & $\begin{array}{c}\text { 合计 Total } \\
\left(\mathrm{kg} \cdot \mathrm{hm}^{-2} \cdot \mathrm{a}^{-1}\right)\end{array}$ \\
$12-16$ & $-1.09^{\mathrm{aN}}$ & $-0.64^{\mathrm{bN}}$ & $-1.46^{\mathrm{cN}}$ & $-1.57^{\mathrm{dN}}$ & $+0.59^{\mathrm{eM}}$ \\
$17-20$ & $-1.79^{\mathrm{aR}}$ & $-0.87^{\mathrm{bR}}$ & $-1.63^{\mathrm{aR}}$ & $-1.18^{\mathrm{dR}}$ & $-1.07^{\mathrm{aN}}$ \\
$21-25$ & $-1.65^{\mathrm{aR}}$ & $-0.71^{\mathrm{bS}}$ & $-1.08^{\mathrm{cS}}$ & $-0.86^{\mathrm{dS}}$ & $-1.28^{\mathrm{dR}}$ \\
\hline
\end{tabular}

“-”, 以前生育阶段生长的植物体内养分中输送到这一生育阶段新生长生物量中的养分; “+”, 这一生育阶段新吸收的养分中流向以前生育阶段现存生 物体内的养分。同一行不同小写字母表示差异显著 $(p<0.05)$; 同一列不同大写字母表示差异显著 $(p<0.05)$ 。

“-”, the nutrient transferred from individuals at the previous stage to the new growth biomass at this stage; “+”, the newly absorbed nutrients in this growth stage that flow to the existing organisms in the previous stage. Different lowercase letters in the same row indicate significant differences $(p<0.05)$, different uppercase letters in the same column indicate significant differences $(p<0.05)$. 
质”(干、皮、枝、叶和根)的平均养分量, 分别为 1.01 、 $1.21 、 2.10 、 0.92$ 和 $0.59 \mathrm{~kg} \cdot \mathrm{hm}^{-2} \cdot \mathrm{a}^{-1}$ 。可见，在 快速生长阶段林分吸收的养分不仅要满足本林龄段 林分生产物质的需要, 而且还要运送一些到“仍存 活物质”。这是杉木在快速生长阶段为了壮大自己的 个体所采取的策略。从运送到“仍存活物质”的各器 官养分量看出, 生理功能越强的器官如叶补充的养 分越多。

林分自第12年起，从“仍存活物质” (干、皮、枝、 叶和根)中迁移出的养分量, 依次是 1.09-1.79、0.64$0.87 、 1.08-1.63 、 0.86-1.57 、 0.88-1.28 \mathrm{~kg} \cdot \mathrm{hm}^{-2} \cdot \mathrm{a}^{-1}$ 。 各器官迁移出来的养分随林龄变化的规律是: 除从 叶中迁移出的养分随林龄增加而减少外, 干、皮、 枝和根中迁移出的养分均随林龄增加呈现先上升后 下降的现象。从表 2 还看出, 当杉木进入干材积累阶 段后, 生理功能越强的器官, 如叶, 转移出来的养 分越少; 生理功能越弱的器官, 如树干、树枝中迁 移出来的养分相对较多。可见, 各器官迁移出来的 养分量也与器官的功能有关。

\section{3 不同林龄段枝、叶枯死前的养分迁移量}

表3表明，1-25年生的林分, 不同林龄段枝叶枯 死前迁移出的养分量为 $3.23-29.28 \mathrm{~kg} \cdot \mathrm{hm}^{-2} \cdot \mathrm{a}^{-1}$ 。其中, 枝的迁移量 $0.19-8.40 \mathrm{~kg} \cdot \mathrm{hm}^{-2} \cdot \mathrm{a}^{-1}$, 占养分总迁移量
的 $5.59 \%-28.68 \%$; 叶的迁移量 $3.04-20.88 \mathrm{~kg} \cdot \mathrm{hm}^{-2} \cdot \mathrm{a}^{-1}$, 占养分总迁移量 $71.32 \%-94.41 \%$ 。由此可见，杉木枝 叶枯死前的养分迁移量绝大部分由叶贡献。枝的养 分迁移量随林龄增加而增加; 叶的养分迁移量在 20 年以前随林龄增加而增加, 20 年以后随林龄增加而 下降。

从表3还可看出，不同林龄段枝叶枯死前的 $\mathrm{N}$ 、 $\mathrm{P} 、 \mathrm{~K} 、 \mathrm{Ca} 、 \mathrm{Mg}$ 迁移量分别是1.30-14.85、0.19-1.91、 $1.41-11.98 、 0.20-2.59 、 0.13-0.59 \mathrm{~kg} \cdot \mathrm{hm}^{-2} \cdot \mathrm{a}^{-1}$, 分别 占总迁移量的 $40.37 \%-47.38 \%$ 、 $5.29 \%-5.97 \%$ 、 $36.37 \%-43.79 \% 、 6.09 \%-8.85 \% 、 1.43 \%-3.97 \%$ 。从 中看出, 枝叶枯死前迁移的养分主要是 $\mathrm{N}$ 和 $\mathrm{K}$, 占总 迁移量的 $83.75 \%-84.25 \%, \mathrm{P} 、 \mathrm{Ca} 、 \mathrm{Mg}$ 的迁移量只占 总迁移量的 $15.75 \%-16.25 \%$ 。不同林龄段枝叶枯死 前迁移的N中，枝占 $3.85 \%-25.74 \%$, 叶占 $74.26 \%-$ $96.15 \%$; 迁移的 P 中, 枝占 $3.23 \%-23.43 \%$, 叶占 $76.57 \%-96.77 \%$; 迁移的 K中，枝占 $7.80 \%-34.84 \%$, 叶占 $65.16 \%-92.20 \%$; 迁移的 Ca中, 枝占 $3.06 \%-$ $22.01 \%$, 叶占 $77.99 \%-96.94 \%$; 迁移的 $\mathrm{Mg}$ 中, 枝占 $6.25 \%-33.33 \%$, 叶占 $66.67 \%-93.75 \%$ 。无论哪一种 养分, 叶的迁移量均占其中绝大部分。

\section{4 不同林龄段林分吸收的土壤养分量}

根据“吸收=存留+归还”的方法(传统方法)计算

表3 杉木枝叶枯死前的养分元素迁移量

Table 3 Average annual nutrient element transferred before death of branches and leaves of Chinese fir

\begin{tabular}{|c|c|c|c|c|c|c|c|}
\hline \multirow{2}{*}{$\begin{array}{l}\text { 林龄 } \\
\text { Stand age (a) }\end{array}$} & \multirow{2}{*}{$\begin{array}{l}\text { 器官 } \\
\text { Organ }\end{array}$} & \multicolumn{5}{|c|}{ 养分元素 Nutrient elements $\left(\mathrm{kg} \cdot \mathrm{hm}^{-2} \cdot \mathrm{a}^{-1}\right)$} & \multirow{2}{*}{$\begin{array}{l}\text { 合计 Total } \\
\left(\mathrm{kg} \cdot \mathrm{hm}^{-2} \cdot \mathrm{a}^{-1}\right)\end{array}$} \\
\hline & & 磷 Phosphorus & 氮 Nitrogen & 钾 Potassium & 钻 Calcium & 镁 Magnesium & \\
\hline \multirow[t]{3}{*}{$1-7$} & 枝 Twig & $0.01^{\mathrm{bA}}$ & $0.05^{\mathrm{aA}}$ & $0.11^{\mathrm{cA}}$ & $0.01^{\mathrm{bA}}$ & $0.01^{\mathrm{bA}}$ & $0.19^{\mathrm{A}}$ \\
\hline & 叶 Needle & $0.18^{\mathrm{bB}}$ & $1.25^{\mathrm{aB}}$ & $1.30^{\mathrm{cB}}$ & $0.19^{\mathrm{bB}}$ & $0.12^{\mathrm{cB}}$ & $3.04^{\mathrm{B}}$ \\
\hline & 合 Total & $0.19^{\mathrm{bB}}$ & $1.30^{\mathrm{aQ}}$ & $1.41^{\mathrm{cQ}}$ & $0.20^{\mathrm{dB}}$ & $0.13^{\mathrm{eQ}}$ & $3.23^{\mathrm{Q}}$ \\
\hline \multirow[t]{3}{*}{$8-11$} & 枝 Twig & $0.04^{\mathrm{bC}}$ & $0.24^{\mathrm{aC}}$ & $0.42^{\mathrm{cC}}$ & $0.03^{\mathrm{dD}}$ & $0.03^{\mathrm{dC}}$ & $0.77^{\mathrm{C}}$ \\
\hline & 叶 Needle & $0.62^{\mathrm{bD}}$ & $5.24^{\mathrm{aD}}$ & $4.62^{\mathrm{cD}}$ & $0.86^{\mathrm{dF}}$ & $0.38^{\mathrm{eD}}$ & $11.72^{\mathrm{D}}$ \\
\hline & 合 Total & $0.66^{\mathrm{bE}}$ & $5.48^{\mathrm{aE}}$ & $5.04^{\mathrm{cE}}$ & $0.89^{\mathrm{dE}}$ & $0.41^{\mathrm{eE}}$ & $12.48^{\mathrm{E}}$ \\
\hline \multirow[t]{3}{*}{$12-16$} & 枝 Twig & $0.15^{\mathrm{bM}}$ & $1.04^{\mathrm{aM}}$ & $1.49^{\mathrm{cM}}$ & $0.16^{\mathrm{dM}}$ & $0.09^{\mathrm{eM}}$ & $2.93^{\mathrm{M}}$ \\
\hline & 叶 Needle & $1.03^{\mathrm{bN}}$ & $8.47^{\mathrm{aN}}$ & $6.76^{\mathrm{cN}}$ & $1.44^{\mathrm{dN}}$ & $0.43^{\mathrm{eN}}$ & $18.13^{\mathrm{N}}$ \\
\hline & 合 Total & $1.18^{\mathrm{bT}}$ & $9.51^{\mathrm{aT}}$ & $8.25^{\mathrm{cT}}$ & $1.60^{\mathrm{dT}}$ & $0.52^{\mathrm{eT}}$ & $21.06^{\mathrm{T}}$ \\
\hline \multirow[t]{3}{*}{$17-20$} & 枝 Twig & $0.39^{\mathrm{bK}}$ & $2.87^{\mathrm{aK}}$ & $3.47^{\mathrm{cK}}$ & $0.45^{\mathrm{dK}}$ & $0.18^{\mathrm{eK}}$ & $7.36^{\mathrm{K}}$ \\
\hline & 叶 Needle & $1.52^{\mathrm{bR}}$ & $11.98^{\mathrm{aR}}$ & $8.51^{\mathrm{cR}}$ & $2.11^{\mathrm{dR}}$ & $0.41^{\mathrm{eR}}$ & $24.53^{\mathrm{R}}$ \\
\hline & 合 Total & $1.91^{\mathrm{bS}}$ & $14.85^{\mathrm{aS}}$ & $11.98^{\mathrm{cS}}$ & $2.56^{\mathrm{dS}}$ & $0.59^{\mathrm{eS}}$ & $31.89^{\mathrm{S}}$ \\
\hline \multirow[t]{3}{*}{$21-25$} & 枝 Twig & $0.41^{\mathrm{bK}}$ & $3.57^{\mathrm{aW}}$ & $3.71^{\mathrm{cW}}$ & $0.57^{\mathrm{dW}}$ & $0.14^{\mathrm{eW}}$ & $8.40^{\mathrm{W}}$ \\
\hline & 叶 Needle & $1.34^{\mathrm{bG}}$ & $10.30^{\mathrm{aG}}$ & $6.94^{\mathrm{cG}}$ & $2.02^{\mathrm{dR}}$ & $0.28^{\mathrm{eG}}$ & $20.88^{\mathrm{G}}$ \\
\hline & 合 Total & $1.75^{\mathrm{bP}}$ & $13.87^{\mathrm{aP}}$ & $10.65^{\mathrm{cP}}$ & $2.59^{\mathrm{dP}}$ & $0.42^{\mathrm{eP}}$ & $29.28^{\mathrm{P}}$ \\
\hline
\end{tabular}

同一行小写字母相同表示差异不显著 $(p>0.05)$; 同一列大写字母相同表示差异不显著 $(p>0.05)$ 。

The same row in the same lowercase letters indicates that the difference is not significant $(p>0.05)$. A certain age in the same column in the same uppercase letter indicates that the difference is not significant $(p>0.05)$. 
的林分的土壤养分吸收量, 以及按公式(7)或公式(8) 计算的林分的土壤养分吸收量都列于表4中。

1-7年生的林分，传统方法计算的林分吸收的 土壤养分为 $90.79 \mathrm{~kg} \cdot \mathrm{hm}^{-2} \cdot \mathrm{a}^{-1}$ 。由于该林龄段不存在 “仍存活物质”，因此也就没有“仍存活物质”的养分 迁移量。但该林龄段内枝叶枯死前迁移的 3.22 $\mathrm{kg} \cdot \mathrm{hm}^{-2} \cdot \mathrm{a}^{-1}$ 养分可再利用, 这就减少了林分对土壤 养分的吸收量，因此，按公式(8)计算得到林分吸收 的土壤养分为 $87.57 \mathrm{~kg} \cdot \mathrm{hm}^{-2} \cdot \mathrm{a}^{-1}$ 。

8-11年生的林分，传统方法计算的林分吸收土 壤养分为 $164.08 \mathrm{~kg} \cdot \mathrm{hm}^{-2} \cdot \mathrm{a}^{-1}$ 。在该林龄段补充到“这 些仍存活的物质”的养分为 $7.83 \mathrm{~kg} \cdot \mathrm{hm}^{-2} \cdot \mathrm{a}^{-1}$, 这增加 了林分对土壤养分的吸收量。但此林龄段枝叶枯死 前迁移的 $12.48 \mathrm{~kg} \cdot \mathrm{hm}^{-2} \cdot \mathrm{a}^{-1}$ 养分的再利用, 又可减少 林分对土壤养分的吸收量。按公式(8)计算得到林分 吸收土壤养分 $159.43 \mathrm{~kg} \cdot \mathrm{hm}^{-2} \cdot \mathrm{a}^{-1}$ 。

12-16年生的林分，从“仍存活物质”迁移出 5.83 $\mathrm{kg} \cdot \mathrm{hm}^{-2} \cdot \mathrm{a}^{-1}$ 养分和该林龄段枯死枝叶中迁移的 21.06 $\mathrm{kg} \cdot \mathrm{hm}^{-2} \cdot \mathrm{a}^{-1}$ 养分可再利用。按公式(7)计算得到林分 平均吸收了 $146.21 \mathrm{~kg} \cdot \mathrm{hm}^{-2} \cdot \mathrm{a}^{-1}$ 土壤中的养分, 比传 统方法计算的 $173.10 \mathrm{~kg} \cdot \mathrm{hm}^{-2} \cdot \mathrm{a}^{-1}$ 少 $26.89 \mathrm{~kg} \cdot \mathrm{hm}^{-2} \cdot \mathrm{a}^{-1}$ 。

$17-20$ 年和 $21-25$ 年两个林龄段与 $12-16$ 年林龄 段相同，都发生了“仍存活物质”迁移出的养分和某 林龄段的枝叶枯死前迁移的养分的再利用。因此, 按公式(7)计算得到这两个林龄段吸收的土壤养分 依次为 160.72 和 $132.73 \mathrm{~kg} \cdot \mathrm{hm}^{-2} \cdot \mathrm{a}^{-1}$, 分别比传统方
法计算的199.36和 $167.19 \mathrm{~kg} \cdot \mathrm{hm}^{-2} \cdot \mathrm{a}^{-1}$ 少 38.64 和 34.46 $\mathrm{kg} \cdot \mathrm{hm}^{-2} \cdot \mathrm{a}^{-1}$ 。

从表4中可看出，任一个林龄时，林分吸收土壤 营养元素的量都是 $N>\mathrm{Ca}>\mathrm{K}>\mathrm{Mg}>\mathrm{P}$ 。1-7年平均 吸收土壤养分 $87.57 \mathrm{~kg} \cdot \mathrm{hm}^{-2} \cdot \mathrm{a}^{-1}, 8-11$ 年上升到 $159.43 \mathrm{~kg} \cdot \mathrm{hm}^{-2} \cdot \mathrm{a}^{-1}, 12-16$ 年下降到 146.21 $\mathrm{kg} \cdot \mathrm{hm}^{-2} \cdot \mathrm{a}^{-1} ， 17-20$ 年又上升到 $160.72 \mathrm{~kg} \cdot \mathrm{hm}^{-2} \cdot \mathrm{a}^{-1}$, 21-25年再降到 $132.73 \mathrm{~kg} \cdot \mathrm{hm}^{-2} \cdot \mathrm{a}^{-1}$, 在1-25年生的林 分内, 吸收的土壤养分随林龄增加呈现上升、下降、 再上升、再下降的变化。

\section{5 不同林龄段杉木体内转移的养分再利用}

1-7 年生的林分, 从土壤吸收养分 87.57 $\mathrm{kg} \cdot \mathrm{hm}^{-2} \cdot \mathrm{a}^{-1}$ (表 4$)$, 从枝叶枯死前迁移的可再利用养 分 $3.22 \mathrm{~kg} \cdot \mathrm{hm}^{-2} \cdot \mathrm{a}^{-1}$ (表3), 用于物质生产的养分共 $90.79 \mathrm{~kg} \cdot \mathrm{hm}^{-2} \cdot \mathrm{a}^{-1}$ 。该林龄段每年生产干物质 6.17 $\mathrm{t} \cdot \mathrm{hm}^{-2}$ (表4), 即生产 $1 \mathrm{t}$ 干物质消耗养分 $14.77 \mathrm{~kg}$, 其 中土壤提供 $14.25 \mathrm{~kg}$ 养分, 枝叶枯死前转移提供 0.52 $\mathrm{kg}$ (表5)。每生产 $1 \mathrm{t}$ 干物质中, 利用土壤养分生产了 $964.8 \mathrm{~kg}$ ，利用枝叶枯死前迁移的养分生产了 35.20 $\mathrm{kg}$ ，枝叶枯死前迁移的养分生产的物质占生产物质 总量的 $3.52 \%$ 。

$8-11$ 年生的林分，从土壤中吸收 159.43 $\mathrm{kg} \cdot \mathrm{hm}^{-2} \cdot \mathrm{a}^{-1}$ 养分(包括输送到“仍存活物质”中 7.83 $\mathrm{kg} \cdot \mathrm{hm}^{-2} \cdot \mathrm{a}^{-1}$ 养分)(表 4 ), 加上每年枝叶枯死前迁移出 $12.48 \mathrm{~kg} \cdot \mathrm{hm}^{-2} \cdot \mathrm{a}^{-1}$ 养分再利用(表3), 因而用于生产 物质的养分共 $171.91 \mathrm{~kg} \cdot \mathrm{hm}^{-2} \cdot \mathrm{a}^{-1}$ 。该林龄段每年生

表4 杉木林在不同林龄阶段年吸收的土壤养分

Table 4 Annual nutrients taken up from soils by Chinese fir plantations at different ages

\begin{tabular}{|c|c|c|c|c|c|c|c|c|}
\hline \multirow{2}{*}{$\begin{array}{l}\text { 林龄 } \\
\text { Stand age (a) }\end{array}$} & \multirow{2}{*}{$\begin{array}{c}\text { 生产力 } \\
\text { Prolificacy } \\
\left(\mathrm{t} \cdot \mathrm{hm}^{-2} \cdot \mathrm{a}^{-1}\right)\end{array}$} & \multirow{2}{*}{$\begin{array}{l}\text { 计算公式 } \\
\text { Calculation formula }\end{array}$} & \multicolumn{5}{|c|}{ 养分元素 Nutrient elements $\left(\mathrm{kg} \cdot \mathrm{hm}^{-2} \cdot \mathrm{a}^{-1}\right)$} & \multirow{2}{*}{$\begin{array}{c}\text { 合计 Total } \\
\left(\mathrm{kg} \cdot \mathrm{hm}^{-2} \cdot \mathrm{a}^{-1}\right)\end{array}$} \\
\hline & & & $\begin{array}{c}\text { 磷 } \\
\text { Phosphorus }\end{array}$ & $\begin{array}{c}\text { 氮 } \\
\text { Nitrogen }\end{array}$ & $\begin{array}{c}\text { 钾 } \\
\text { Potassium }\end{array}$ & $\begin{array}{c}\text { 钙 } \\
\text { Calcium }\end{array}$ & $\begin{array}{c}\text { 镁 } \\
\text { Magnesium }\end{array}$ & \\
\hline \multirow[t]{2}{*}{$1-7$} & 6.17 & ARR & 2.92 & 30.43 & 21.44 & 28.66 & 7.54 & 90.79 \\
\hline & & 公式(8) Formula (8) & 2.74 & 29.18 & 20.14 & 28.47 & 7.42 & 87.57 \\
\hline \multirow[t]{2}{*}{$8-11$} & 10.63 & ARR & 5.60 & 57.30 & 36.45 & 50.26 & 14.47 & 164.08 \\
\hline & & 公式(8) Formula (8) & 5.31 & 54.93 & 32.77 & 51.33 & 15.09 & 159.43 \\
\hline \multirow[t]{2}{*}{$12-16$} & 11.31 & ARR & 5.79 & 61.09 & 37.79 & 53.10 & 15.35 & 173.10 \\
\hline & & 公式(7) Formula (7) & 4.18 & 50.17 & 28.27 & 49.60 & 13.99 & 146.21 \\
\hline \multirow[t]{2}{*}{$17-20$} & 16.51 & ARR & 6.72 & 73.30 & 44.69 & 58.24 & 16.41 & 199.36 \\
\hline & & 公式(7) Formula (7) & 4.28 & 56.79 & 31.31 & 53.42 & 14.92 & 160.72 \\
\hline \multirow[t]{2}{*}{$21-25$} & 14.45 & ARR & 5.61 & 60.77 & 38.46 & 48.66 & 13.70 & 167.19 \\
\hline & & 公式(7) Formula (7) & 3.45 & 45.60 & 26.75 & 44.30 & 12.63 & 132.73 \\
\hline
\end{tabular}

ARR，表示“吸收=存留+归还”。

$\mathrm{ARR}$, means "absorption = retention + return".

www.plant-ecology.com 
表5＼cjkstart杉木林生产 $1 \mathrm{t}$ 整树干物质所需养分及来源

Table 5 Nutrients and sources needed for producing $1 \mathrm{t}$ dry biomass in Chinese fir plantations

\begin{tabular}{|c|c|c|c|c|c|c|c|}
\hline \multirow{2}{*}{$\begin{array}{l}\text { 林龄 } \\
\text { Stand age } \\
\text { (a) }\end{array}$} & \multirow{2}{*}{$\begin{array}{l}\text { 养分来源 } \\
\text { Source of nutrients }\end{array}$} & \multicolumn{5}{|c|}{ 养分元素 Nutrient elements $\left(\mathrm{kg} \cdot \mathrm{hm}^{-2} \cdot \mathrm{a}^{-1}\right)$} & \multirow{2}{*}{$\begin{array}{l}\text { 合计 Total } \\
\left(\mathrm{kg} \cdot \mathrm{hm}^{-2} \cdot \mathrm{a}^{-1}\right)\end{array}$} \\
\hline & & $\begin{array}{c}\text { 磷 } \\
\text { Phosphorus }\end{array}$ & $\begin{array}{c}\text { 氮 } \\
\text { Nitrogen }\end{array}$ & $\begin{array}{c}\text { 钾 } \\
\text { Potassium }\end{array}$ & $\begin{array}{c}\text { 钲 } \\
\text { Calcium }\end{array}$ & $\begin{array}{c}\text { 镁 } \\
\text { Magnesium }\end{array}$ & \\
\hline \multirow[t]{4}{*}{$1-7$} & 土壤中吸收 Absorbed from the soil & 0.44 & 4.73 & 3.26 & 4.62 & 1.20 & 14.25 \\
\hline & 衰老枝叶回流 Return from senescent branches and leaves & 0.03 & 0.21 & 0.23 & 0.03 & 0.02 & 0.52 \\
\hline & TPGM & 0 & 0 & 0 & 0 & 0 & 0 \\
\hline & 合计 Total & 0.47 & 4.94 & 3.49 & 4.65 & 1.22 & 14.77 \\
\hline \multirow[t]{4}{*}{$8-11$} & ASNAPGM & 0.50 & 5.17 & 3.08 & 4.83 & 1.42 & 15.00 \\
\hline & 衰老枝叶回流 Return from senescent branches and leaves & 0.06 & 0.52 & 0.47 & 0.08 & 0.04 & 1.17 \\
\hline & TPGM & 0 & 0 & 0 & 0 & 0 & 0 \\
\hline & 合计 Total & 0.56 & 5.69 & 3.55 & 4.91 & 1.46 & 16.17 \\
\hline \multirow[t]{4}{*}{$12-16$} & 土壤中吸收 Absorbed from the soil & 0.37 & 4.44 & 2.50 & 4.39 & 1.23 & 12.93 \\
\hline & 衰老枝叶回流 Return from senescent branches and leaves & 0.10 & 0.84 & 0.73 & 0.14 & 0.05 & 1.86 \\
\hline & TPGM & 0.05 & 0.10 & 0.13 & 0.14 & 0.10 & 0.52 \\
\hline & 合计 Total & 0.52 & 5.38 & 3.36 & 4.67 & 1.38 & 15.31 \\
\hline \multirow[t]{4}{*}{$17-20$} & 土壤中吸收 Absorbed from the soil & 0.26 & 3.44 & 1.90 & 3.23 & 0.90 & 9.73 \\
\hline & 衰老枝叶回流 Return from senescent branches and leaves & 0.12 & 0.89 & 0.72 & 0.16 & 0.04 & 1.93 \\
\hline & TPGM & 0.05 & 0.11 & 0.10 & 0.07 & 0.08 & 0.41 \\
\hline & 合计 Total & 0.43 & 4.44 & 2.72 & 3.46 & 1.02 & 12.07 \\
\hline \multirow[t]{4}{*}{$21-25$} & 从土壤中吸收 Absorbed from the soil & 0.24 & 3.16 & 1.85 & 3.06 & 0.87 & 9.18 \\
\hline & 衰老枝叶回流 Return from senescent branches and leaves & 0.12 & 0.96 & 0.74 & 0.18 & 0.03 & 2.03 \\
\hline & TPGM & 0.03 & 0.09 & 0.07 & 0.12 & 0.05 & 0.36 \\
\hline & 合计 Total & 0.39 & 4.21 & 2.66 & 3.36 & 0.95 & 11.57 \\
\hline
\end{tabular}

ASNAPGM，表示从土壤中吸收(包括补充到 8 年以前生长的，在此林龄段内仍存活的物质中)的养分; TPGM，表示从以前生长的在该林龄段还活着的 物质中迁移出的养分。

ASNAPGM, which is taken from the soil (including nutrients added to substances that survived 8 years ago and survived in this forest age); TPGM, which refers to nutrients transferred from previously grown materials that are still alive in this forest age.

产干物质 $10.63 \mathrm{t} \cdot \mathrm{hm}^{-2}$ (表4), 每生产 $1 \mathrm{t}$ 干物质所需 的 $16.17 \mathrm{~kg}$ 养分中, 从土壤中吸收和枝叶枯死前迁 移的养分分别为 15.00 和 $1.17 \mathrm{~kg}$ (表5)。每生产 $1 \mathrm{t}$ 干 物质中, 有 $927.6 \mathrm{~kg}$ 干物质是利用土壤养分生产的, 有 $72.4 \mathrm{~kg}$ 干物质是利用枝叶枯死前迁移的养分生产 的，分别占生产干物质总量的 $92.76 \%$ 和 $7.24 \%$ 。

12-16年生的林分，用于物质生产的养分来自3 个方面, 一是林分吸收的土壤养分 146.21 $\mathrm{kg} \cdot \mathrm{hm}^{-2} \cdot \mathrm{a}^{-1}$ (表 4$)$, 二是 “仍存活物质”迁移出养分 $5.83 \mathrm{~kg} \cdot \mathrm{hm}^{-2} \cdot \mathrm{a}^{-1}$ (表2), 再是枝叶枯死前迁移出养分 $21.06 \mathrm{~kg} \cdot \mathrm{hm}^{-2} \cdot \mathrm{a}^{-1}$ (表3)。该林龄段林分每年生产干 物质 $11.31 \mathrm{t} \cdot \mathrm{hm}^{-2}$ (表4)。每生产 $1 \mathrm{t}$ 干物质需要 15.31 $\mathrm{kg}$ 养分，其中，土壤吸收的、枝叶枯死前迁移的、“仍 存活物质”迁移出的养分分别为 $12.93 、 1.86$ 和 $0.52 \mathrm{~kg}$ (表5)。该林龄段林分每生产 $1 \mathrm{t}$ 干物质, 从“仍存活物 质”迁移出的养分再利用生产了 $34 \mathrm{~kg}$, 从枝叶调落 前迁移的养分再利用生产了 $121.5 \mathrm{~kg}$, 分别占生产
物质总量的 $3.40 \%$ 和 $12.15 \%$ 。

17-20年生的林分，用于物质生产的养分有“仍 存活物质” 中迁移出的养分 $6.75 \mathrm{~kg} \cdot \mathrm{hm}^{-2} \cdot \mathrm{a}^{-1}$ (表2), 枝叶枯死前迁移的养分 $31.89 \mathrm{~kg} \cdot \mathrm{hm}^{-2} \cdot \mathrm{a}^{-1}$ (表3), 从 土壤吸收的养分 $160.72 \mathrm{~kg} \cdot \mathrm{hm}^{-2} \cdot \mathrm{a}^{-1}$ (表4), 共计 $199.36 \mathrm{~kg} \cdot \mathrm{hm}^{-2} \cdot \mathrm{a}^{-1}$ 。该林龄段每年生产 $16.51 \mathrm{t} \cdot \mathrm{hm}^{-2}$ 干物质(表 4$)$ 。从表 5 可知每生产 $1 \mathrm{t}$ 干物质消耗土壤 养分 $9.73 \mathrm{~kg}$ ，消耗枝叶枯死前迁移的养分 $1.93 \mathrm{~kg}$, 消耗“仍存活物质”迁移出的养分 $0.41 \mathrm{~kg}$ 。林分每年 生产的 $16.51 \mathrm{t} \cdot \mathrm{hm}^{-2}$ 干物质中, 利用枝叶枯死前迁移 的养分生产了 $2.32 \mathrm{t} \cdot \mathrm{hm}^{-2} \cdot \mathrm{a}^{-1}$, 利用“仍存活物质”迁 移出的养分生产了 $0.56 \mathrm{t} \cdot \mathrm{hm}^{-2} \cdot \mathrm{a}^{-1}$, 分别占林分生产 物质总量的 $15.99 \%$ 和 $3.40 \%$ 。

21-25年生的林分, 生产干物质 $14.45 \mathrm{t} \cdot \mathrm{hm}^{-2} \cdot \mathrm{a}^{-1}$ (表4), 共消耗养分 $168.69 \mathrm{~kg} \cdot \mathrm{hm}^{-2} \cdot \mathrm{a}^{-1}$ 。其中, 消耗土 壤中的养分 $132.73 \mathrm{~kg} \cdot \mathrm{hm}^{-2} \cdot \mathrm{a}^{-1}$ (表4), 枝叶枯死前迁 移的养分 $26.28 \mathrm{~kg} \cdot \mathrm{hm}^{-2} \cdot \mathrm{a}^{-1}$ (表3), 从“仍存活物质” 
迁移出的养分 $5.18 \mathrm{~kg} \cdot \mathrm{hm}^{-2} \cdot \mathrm{a}^{-1}$ (表 2 )。那么每生产 $1 \mathrm{t}$ 干物质需利用养分 $11.57 \mathrm{~kg}$, 其中, 利用土壤中的养 分 $9.18 \mathrm{~kg}$, 利用“仍存活物质”迁移出的养分 $0.36 \mathrm{~kg}$, 利用枝叶调落前迁移的养分 $2.03 \mathrm{~kg}$ (表5)。林分生产 的 $14.45 \mathrm{t} \cdot \mathrm{hm}^{-2} \cdot \mathrm{a}^{-1}$ 干物质中, 利用枝叶枯死前迁移 的和 “仍存活物质”迁移出的养分分别生产了 2.54 和 $0.45 \mathrm{t} \cdot \mathrm{hm}^{-2} \cdot \mathrm{a}^{-1}$, 分别占生产物质总量的 $17.55 \%$ 和 $3.11 \%$ 。

从上面分析看出, 林分物质生产过程中, 利用 的枝叶枯死前迁移的养分生产的物质占生产物质总 量的比例，从 1-7年生的林分的 $3.52 \%$ 持续上升到 21-25年生的林分的 $17.55 \%$ 。只有林龄达到12年后, 才发生从“仍存活物质”中迁移出的养分的再利用。 利用 “仍存活物质”迁移出的养分生产的物质, 占林 分生产物质总量的 $3.11 \%-3.40 \%$ 。

\section{3 讨论}

会同杉木枝叶枯死前 $\mathrm{N} 、 \mathrm{P} 、 \mathrm{~K}$ 迁移率大于Ca、 $\mathrm{Mg}$ 。各养分元素迁移率与福建杉木(周丽丽, 2014) 相比, 除叶的 $\mathrm{Mg}$ 相近外, 其余枝叶中各元素转移率 均低于福建杉木。与林宝平等(2017)研究的杉木相 比, $\mathrm{P} 、 \mathrm{Ca}$ 转移率偏高, $\mathrm{N} 、 \mathrm{~K} 、 \mathrm{Mg}$ 则偏低。与其他研 究结果存在差别可能是如下原因造成的: (1)研究林 分的立地环境条件不相同, 同一树种在不同的立地 环境条件下可能造成枝叶枯死前后养分浓度的差异, 进而导致枝叶枯死前养分迁移率的差异。(2)研究方 法不同, 本研究是在同一林分内连续定位测定不同 林龄时的数据，其他同类研究大都用“空间换时间” 法, 空间的异质性可能导致其研究结果偏移。(3)本 研究把1-25年生的林分分成几个连续的林龄段, 依 据每林龄段前后测定数据分段逐一分析, 同类研究 则是在林分某一林龄时测定数据，把林分 1 年生到 这个林龄时作为一个时间序列处理, 所取的时间尺 度不一样, 导致研究结果也不一样。

从本研究结果看出, 会同1-25年生杉木林生产 的物质中, 有 $3.52 \%-17.55 \%$ 是利用枝叶枯死前迁移 的养分生产的, 有 $3.11 \%-3.40 \%$ 是利用“仍存活物 质”迁移出的养分生产的。可见，用于林分物质生产 的养分并不都来自土壤。如果忽略林分物质生产中 对植物组织衰老时迁移的和“仍存活物质”迁移出的 养分的再利用, 就不能真实地反映林分养分利用特 征，而且也可能会低估林分对养分的利用效率。
枝叶枯死前迁移的养分，以及这些养分生产的 物质占生产物质总量的比例都随林龄增加而增大。 这是由不同林龄林分的枝叶枯死量决定的。杉木是 常绿树种, 枝叶都有一定的生长周期, 当年生长的 枝叶不会在当年枯死, 要到它生长周期的后期才会 死亡。从图1可以看出, 杉木从幼树到干材积累阶段 (1-20年生), 叶的生产量逐年增加。这些不同年份生 长的叶完成它的生长期后逐渐死亡, 所以随林龄增 加叶枯死量逐渐增多, 叶枯死前迁移的养分也逐渐 增多, 再用于物质生产的养分也增多。可见, 树木生 长发育特征和枝叶的生理特性控制着枝叶枯死前的 养分迁移和再利用的年变化规律。

会同杉木林生长 12 年时, 才发生某林龄段“仍 存活物质”迁移出养分用于物质生产。这主要由杉木 不同生长阶段对养分的不同需求引起的。杉木从幼 树到快速生长阶段为了壮大自己的个体, 为树木未 来生长打好基础, 已生产的物质(器官)中需要不断 补充养分。因此，这个生育阶段的“仍存活物质”中 不仅没有养分转移出来再利用, 而且还需要新的养 分补充。如本研究中 $8-11$ 年生的林分吸收的土壤养 分中, 每年还需输送7.83 $\mathrm{kg} \cdot \mathrm{hm}^{-2}$ 到该林龄段“仍存 活物质”内(表2)。此外, Miller (1986)的研究表明, 林 分郁闭后, 多年生乔木林生产单位物质所需的养分 量减少。树木体内养分再分配机制控制着将积累在 “仍存活物质”内的养分迁移出来重新用于物质生 产。从本研究结果看, 林分生长12年后(杉木林已郁 闭), 虽然从“仍存活物质”内迁移出的养分并不很多, 但“仍存活物质”迁移出的养分生产的物质量仍占生 产物质总量的 $3.11 \%-3.40 \%$ 。这是因为, 树木体内需 要一定的养分量才能正常生长, 只有超过生长需要 的那部分积累的养分才能迁移出来再利用(Miller, 1986; Marschner et al., 1997; Chen \& Brassan, 2013)。 从本研究还可看出, 会同杉木林郁闭后, “仍存活物 质”有一个较为稳定的速率迁移出养分重新用于物 质生产。

植物组织的养分迁移是植物对养分贫㾑环境的 一种适应机制, 也是植物保存养分并维持体内养分 平衡的一种重要的养分利用策略(Kobe et al., 2005; Milla et al., 2005; Huang \& Wang, 2007; Hosseini et al., 2008)。然而, 植物组织迁移养分的机制是什么? 这些迁移的养分是如何被活化重新用于物质生产的? 对于植物组织迁移养分的机制, 有研究提出, 土壤 
贫㾑生境中植物养分再吸收效率高于土壤肥沃生境 中的植物, 土壤贫痊的胁迫作用可能是植物组织养 分迁移的机理(Moghaddas \& Stephens, 2007)。也有 研究指出, 植物组织的养分再吸收与土壤养分供给 性相关不大, 贫痊土壤并不一定是植物体养分迁移 的驱动力(Del Arco et al., 1991; Eckstein \& Karlsson, 1997; Aerts \& Chapin, 1999; 王希华等, 2004)。一些 研究者用植物生理中“源-汇”理论分析植物组织内 养分迁移机制, 认为树木器官在某些生理条件下是 养分的“源”, 在另一些生理条件下可能是“汇”。正 这种“源-汇”作用调控着树木体内的养分迁移 (Marschner et al., 1997)。如本研究中杉木快速增长 阶段, 由于树木要壮大自己的个体, 因而将部分从 土壤吸收的养分输送到“仍存活物质”内。这时杉木 各器官成了养分的“汇”。当林分郁闭后, 生产单位 生物量所需养分量下降(Miller, 1986), 积累在“仍存 活物质”内的养分被迁移出来用于新的物质生产, 这时杉木各器官成了养分的“源”。也有学者认为, 树木体内养分迁移的机理是植物本身具有这种自我 调控的反馈机制, 这种调控机制是植物在自然界长 期的生存竞争中形成的(Killingbeck, 1996; Harrington et al., 2001)。可见, 对于植物组织养分迁移的机 制还没有一个被广泛认可的解析。目前, 迁移的养 分如何被活化且重新用于物质生产的机理研究, 更 是一个非常薄弱的环节。树木体内的养分迁移及养 分再利用是一个非常复杂的生理生化过程, 人们对 此还缺乏基本的了解。因此, 揭示树木体内养分迁 移和再利用的调控机制是生理生态学亟待解决的重 要问题。

杉木林某林龄时调落在林地的枝叶量与某林龄 时的枯死枝叶量是不相等的。这是因为杉木枯死枝 叶的宿存性, 枯死枝叶不会立即从树上掉落, 有些 还残存在树上。如果用某林龄时调落在林地的枝叶 量估算某林龄时的枯死枝叶量, 就有可能忽略了那 些存留在树上的枯死枝叶。此外, 那些存留在树上 的枯死枝叶由于雨水的风化作用, 掉落后其养分含 量有可能低于刚枯死的枝叶。因此, 本研究不同林 龄时杉木枝叶的枯死量是根据杉木枝叶生长周期估 算的, 而不是用某林龄时收集的林地凋落枝叶量估 算的。而且测定枯死枝叶的养分样品不是从林地凋 落枝叶中收集, 而是在活树上采集的, 这样就不用 考虑枯死的枝叶是残存在树上还是掉落, 克服了枯
死枝叶在树上宿存的影响，同时也弥补了刚枯死枝 叶和调落枝叶的养分浓度差异的缺陷。由此推算出 的不同林龄时枝叶枯死前迁移的养分及其再利用量, 所得的结果更接近实际。

本文虽然分析了“仍存活物质”中根的迁移养分 的再利用, 也探讨了枝叶枯死前的养分迁移。但是, 植物细根在枯死前也存在养分转移, 而且这种养分 循环对提高植物养分利用效率意义重大(Meier et al., 1985; Ratnam \& Sankara, 2008)。由于很难准确估测 细根的枯死量, 本文没有研究细根在枯死前转移的 养分, 因此, 本研究得出的杉木枯死组织迁移的养 分量要低于它的实际迁移量。

\section{4 结论}

(1)会同杉木林只要有枝叶枯死发生, 枝叶枯死 前就有养分迁移出来用于物质再生产。枝叶枯死前 迁移的再利用的养分, 以及这些养分生产的物质占 总生产生物量的比例随林龄增加而增大。枝叶枯死 前迁移的养分再利用的年变化受树木生长发育特征 和枝叶的生理特性控制。

(2)会同杉木林郁闭后, 才发生“仍存活物质”迁 移出的养分的再利用。这与不同生长发育阶段树木 器官对养分的需求不同, 以及与林木体内的养分调 节机制采取的策略有关。林分郁闭后，“仍存活物质” 内有一个较为稳定的速率迁移出养分重新用于物质 生产。

(3)会同1-25年生的杉木林内, 每年生产的物质 中有 $3.52 \%-17.55 \%$ 是利用枝叶枯死前转移的养分 生产的; $12-25$ 年生的林分内, 有 $3.11 \%-3.40 \%$ 是利 用某林龄段“仍存活物质”迁移出的养分生产的。枝 叶枯死前迁移的养分和“仍存活物质”迁移出的养分 也参与了林分物质生产过程。忽略了枝叶枯死前迁 移的养分和“仍存活物质”迁移出的养分再利用, 就 不能真实地反映林分养分利用特征和林分对养分的 吸收和利用策略。

\section{参考文献}

Aerts R (1990). Nutrient use efficiency in evergreen and deciduous species from heath lands. Oecologia, 84, 391-397.

Aerts R, Chapin III FS (1999). The mineral nutrition of wild plants revisited: A reevaluation of processes and patterns. Advances in Ecological Research, 37, 1-67.

An Z, Niu DC, Wen HY, Yang Y, Zhang HR, Fu H (2011). 
Effects of $\mathrm{N}$ addition on nutrient resorption efficiency and C:N:P stoichiometric characteristics in Stipa bungeana of steppe grass lands in the Loess Plateau, China. Chinese Journal of Plant Ecology, 35, 801-807. [安卓, 牛得草, 文海燕, 杨益, 张洪荣, 傅华 (2011). 氮素添加对黄土 高原典型草原长芒草氮磷重吸收率及 $\mathrm{C}: \mathrm{N}: \mathrm{P}$ 化学计量特 征的影响. 植物生态学报, 35, 801-807.]

Cao JH, Tao ZL, Jiang JS, Xie GS, Zhao CM (2010). Nutrient use efficiency of clone PR107 at various age. Chinese Journal of Tropical Crops, 31, 2091-097. [曹建华, 陶忠 良, 蒋菊生, 谢贵水, 赵春梅 (2010). 不同年龄橡胶树 PR107养分利用效率研究. 热带作物学报, 31, 2091-2097.]

Chen HYH, Brassard BW (2013). Intrinsic and extrinsic controls of fine root life span. Critical Reviews in Plant Sciences, 32, 151-161.

Chen RS, Kang WX, Zhou YQ, Tian DL, Xiang WH (2018). Changes in nutrient cycling with age in a Cunninghamia lanceolata plantation forest. Chinese Journal of Plant Ecology, 42，173-184. [陈日升, 康文星, 周玉泉, 田大 伦, 项文化 (2018). 杉木人工林养分循环随林龄变化的 特征. 植物生态学报, 42, 173-184.]

Del Arco JM, Esucdero A, Garrido MV (1991). Effects of site characteristics on nitrogen retrains location from senescing leaves. Ecology, 58, 701-708.

Deng HJ, Chen AM, Yan SW, Lin YM, Zhang GS, Du K, Wu CZ, Hong W (2015). Nutrient resorption efficiency and $\mathrm{C}: \mathrm{N}: \mathrm{P}$ stoichiometry in different ages of Leucaena leucocephala. Chinese Journal of Applied and Environmental Biology, 21，522-527. [邓浩俊, 陈爱民, 严思维, 林勇 明, 张广帅, 杜锟, 吴承祯, 洪伟 (2015). 不同林龄新 银合欢重吸收率及其 $\mathrm{C}: \mathrm{N}: \mathrm{P}$ 化学计量特征. 应用与环境 生物学报, 21, 522-527.]

Division of Science and Technology of Ministry of Forestry Compiles (1994). Forest Ecosystem Research Methods. China Science and Technology Press, Beijing. 156-158. [林业部科技司 (1994). 森林生态系统研究方法. 中国 科学技术出版社, 北京. 156-158.]

Eckstein RL, Karlsson PS (1977). Above-ground growth and nitrogen use by plant in a subarctic environment: Effects of habitat life-form and species. Oikos, 311-324.

Harrington RA, Fownes JH, Vitousek PM (2001). Production and resource use efficiencies in $\mathrm{N}$ - and P-limited tropical forests: A comparison of responses to long-term fertilization. Ecosystems, 4, 646-657.

He B, Qin WM, Yu HG, Liu YH, Qin L, Qin YH (2007). Biological cycling of nutrients in different ages classes of Acacia mangium plantation. Acta Ecologica Sinica, 27, 5158-5167. [何斌, 秦武明, 余浩光, 刘运华, 覃林, 覃 永华 (2007). 不同年龄阶段马占相思(Acacia mangium) 人工林营养元素的生物循环. 生态学报, 27 , 5158-5167.]
Hosseini SM, Rouhi-Moghaddam E, Ebrahimi E (2008). Comparison of growth, nutrition and soil properties of pure stands of Quercus castaneifolia and mixed with Zelkova carpinifolia in the Hyrcanian forests of Iran. Forest Ecology and Management, 255, 1149-1160.

Huang JJ, Wang XH (2007). Leaf nutrient concentration, nutrient resorption and litter decomposition in an evergreen broad-leaved forest in eastern China. Forest Ecology and Management, 239, 150-158.

Killingbeck KT (1986). The terminological jungle revisited: Making a case for use of the term resorption. Oikos, 46, 263-264.

Killingbeck KT (1996). Nutrient in senesced leaves: Keys to the search for potential resorption and resorption proficiency. Ecology, 77, 1716-1727.

Kobe RK, Lepcryk CA, Iyer M (2005). Resorption efficiency decreases with increasing green leaf nutrients in a global data set. Ecology, 86, 2780-2792.

Li QL, Mo QF, Wang FM, Li YW, Xu X, Zou B, Li XB, Chen Y, Li ZA (2015). Nutrient utilization by Casuarina equisetifolia plantation of different ages in the tropical coastal area of South China. Chinese Journal of Applied and Environmental Biology, 21, 139-146. [李钦禄, 莫其锋, 王 法明, 李应文, 徐馨, 邹碧, 李晓波, 陈瑶, 李志安 (2015). 华南热带沿海不同林龄木麻黄人工林养分利用 特征. 应用与环境生物学报, 21, 139-146.]

Lim MT, Cousens JF (1986). The internal transfer of nutrients in Scot pine stand 2. The patterns of transfer and the effects of nitrogen availability. Forestry, 59, 17-21.

Lin BP, He ZM, Lin SZ, Hu HT, Qiu LJ, Liu ZM (2017). Needles macronutrient concentrations and retrains location characteristics in Chinese fir plantations of different ages. Journal of Forest and Environment, 37(1), 34-39. [林宝 平, 何宗明, 林思祖, 胡欢甜, 邱岭军, 刘桌明 (2017). 不同林龄杉木针叶大量元素转移特征. 森林与环境学 报, 37(1), 34-39.]

Lin DX, Liu KH, Luo SF (2002). Dynamics and cycling analysis of nutrient elements in Eucalyptus urophylla. Chinese Journal of Applied and Environmental Biology, 8, 148-153. [林德喜, 刘开汉, 罗水发 (2002). 尾叶桉营 养元素动态和循环分析. 应用与环境生物学报, 8 , 148-153.]

Liu AQ, Fan SH, Lin KM, Ma XQ, Sheng WT (2005). Comparison on nutrient cycling in different generation plantations of Chinese fir. Plant Nutrition and Fertilizer Science, 11，273-278. [刘爱琴, 范少辉, 林开敏, 马祥庆, 盛炜 剘 (2005). 不同栽植代数杉木林养分循环的比较研究. 植物营养与肥料学报, 11, 273-278.]

Marschner H, Kirkby EA, Engels C (1997). Importance of cycling and recycling of mineral nutrients within plants for growth and development. Botanica Acta, 110, 265-273.

Mayor JR, Wright SJ, Turner BL (2013). Species-specific

www.plant-ecology.com 
responses of foliar nutrients to long-term nitrogen and phosphorus additions in a lowland tropical forest. Journal of Ecology, 102, 36-44.

Mei L, Wang ZQ, Cheng YH, Guo DL (2004). A review: Factors influencing fine root longevity in forest ecosystems. Acta Phytoecologica Sinica, 28, 704-710. [梅莉, 王政权, 程云环, 郭大立 (2004). 林木细根寿命及其影响因子研 究进展. 植物生态学报, 28, 704-710.]

Meier CE, Grier CC, Cole DW (1985). Below and ground N and $\mathrm{P}$ use by Abies amabilis stands. Ecology, 66, 1928-1942.

Milla R, Castro-Diez P, Maestro-Martinez M (2005). Does the gradualness of leaf shedding govern nutrient resorption from senescing leaves in Mediterranean woody plants? Plant and Soil, 278, 303-313.

Miller HG (1984). Dynamics of nutrient cycling in plantation ecosystems. In: Bowen GD, Nambiar EKS eds. Nutrition of Plantation Forests. Academic Press, London. 53-78.

Miller HG (1986). Carbon $\times$ nutrient interaction-The limitations to productivity. Tree Physiology, 2, 373-385.

Moghaddas EEY, Stephens SL (2007). Thinning burning and thin-burn fuel treatment effects on soil properties in a Sierra Nevada mixed conifer forests. Forest Ecology and Management, 250, 156-166.

Ratnam J, Sankaran M (2008). Hanan in a tropical savanna: Variation N, P nutrient resorption patterns of plant functional groups and functional significance. Oecologia, 157, 141-151.

Shaver GR, Melillo JM (1984). Nutrient budgets of marsh plants: Efficiency concepts and relation to availability. Ecology, 65, 1491-1510.

Tian DL, Shen Y, Kang WX, Xiang WH, Yan WD, Deng XW (2011). Characteristics of nutrient cycling in first and second rotations of Chinese fir plantations. Acta Ecologica Sinica, 31, 5025-5032. [田大伦, 沈燕, 康文星, 项文化, 间文德, 邓湘雯 (2011). 连栽第 1 和第 2 代杉木人工林养 分循环的比较. 生态学报, 31, 5025-5032.]

Wang RL, Cheng RM, Xiao WF, Feng XH, Liu ZB, Wang XR (2012). Influencing factors of fine root production and turnover in forest ecosystem. World Forestry Research, 21(1), 19-24. [王瑞丽, 程瑞梅, 肖文发, 封晓辉, 刘泽 涁, 王晓荣 (2012). 森林细根生产和周转的影响因素. 世界林业研究, 21(1), 19-24.]

Wang XH, Huang JJ, Yan ER (2004). A study on leaf nutrient resorption of some trees in Tiantong National Forest Park. Chinese Journal of Ecology, 33(4), 13-16. [王希华, 黄建 军, 间恩荣 (2004). 天童国家森林公园若干树种叶水平 上养分利用效率的研究. 生态学杂志, 33(4), 13-16.]

Williams RF (1955). Redistribution of mineral elements during development. Annual Review of Plant Physiology, 6, 25-42.

Wu PF, Ma XQ (2009). Research advances in the mechanisms of high nutrient use efficiency in plants. Acta Ecologica Sinica, 29, 427-437. [吴鹏飞, 马祥庆 (2009). 植物养分 高效利用机制研究进展. 生态学报, 29, 427-437.]

Xiang WH, Tian DL (2002). Nutrient cycling in Pinus massoniana stands of different age classes. Acta Phytoecologica Sinica, 26, 89-95. [项文化，田大伦 (2002). 不同年龄阶 段马尾松人工林养分循环的研究. 植物生态学报, 26 , 89-95.]

Xiao XC, Li ZH, Tang ZJ, Zeng Q, Wang HF (2013). Effects of stand density on nutrient cycling rate and use efficiency of Pinus elliottii plantation. Chinese Journal of Ecology, 32, 2871-2880. [肖兴翠, 李志辉, 唐作钧, 曾琴, 王海风 (2013). 林分密度对湿地松人工林养分循环速率和利用 效率的影响. 生态学杂志, 32, 2871-2880.]

Ye GF (2012). Age-related changes in nutrient resorption patterns and tannin concentration of Casuarina equisetifolia plantations. Journal of Tropical Forest Science, 24, 546-556.

Zeng DH, Chen GS, Chen FS, Zhao Q, Ji XY (2005). Foliar nutrients and their resorption efficiencies in four Pinus sylvestris var. mongolica plantations of different ages on sandy soil. Scientia Silvae Sinicae, 41(5), 21-27. [曾德慧, 陈广生, 陈伏生, 赵琼, 冀小燕 (2005). 不同林龄樟子 松叶片养分含量及其再吸收效率. 林业科学, 41(5), 21-27.]

Zeng Q, Gao GW, Lin YM, Fan HQ (2008). Resorption efficiencies of nitrogen and phosphorus of leaves during senescence for two growth forms of Avicennia marina. Journal of Xiamen University (Natural Science), 47, 181-185. [曾琦, 高国伟, 林益明, 范航清 (2008). 红树 植物白骨壤叶片衰老过程的氮磷内吸收变化研究. 厦 门大学学报(自然科学版), 47, 181-185.]

Zhang LH, Lin YM, Ye GF, Yin L, Zhou HC (2009). Nitrogen and phosphorus concentrations, $\mathrm{N}: \mathrm{P}$ ratio and resorption efficiency of leaves in different forest types. Journal of Beijing Forestry University, 31(5), 67-72. [张立华, 林益 明, 叶功富, 殷亮, 周海超 (2009). 不同林分类型叶片 氮磷含量, 氮磷比及其内吸收率. 北京林业大学学报, 31(5), 67-72.]

Zhao Q, Liu XY, Hu YL, Zeng DH (2010). Effects of nitrogen addition on nutrient allocation and nutrient resorption efficiency in Larix gmelinii. Scientia Silvae Sinicae, 46(5), 14-19. [赵琼, 刘兴宇, 胡亚林, 曾德慧 (2010). 氮添加 对兴安落叶松养分分配和再吸收效率的影响. 林业科 学, 46(5), 14-19.]

Zheng Y, Guo YR, Wang MT, Li M, Fan RR, Sun J, Yang FC, Zhong QL, Cheng DL (2017). Foliar nutrients and their resorption efficiencies of Pinus hwangshanensis along an elevation gradient of Wuyi Mountains in Jiangxi. Journal of Anhui Agricultural University, 44, 415-421. [郑媛, 郭 英荣, 王满堂, 李曼, 范瑞瑞, 孙俊, 杨福春, 钟全林, 程栋梁 (2017). 武夷山不同海拔梯度黄山松叶片养分 
含量及其再吸收效率. 安徽农业大学学报, 44, 415-421.]

Zhou LL (2014). Study on Nutrient Retranslocation and Nutrient Use Efficiency in Different Developmental-Staged Chinese Fir Plantations. PhD dissertation, Fujian Agriculture and Forestry University, Fuzhou. 80-82. [周丽丽 (2014). 不同发育阶段杉木人工林养分内循环与周转利 用效率的研究. 博士学位论文, 福建农林大学, 福州. 80-82.]
Zong N, Shi PL, Geng SB, Ma WL (2017). Nitrogen and phosphorus resorption efficiency of forests in North China. Chinese Journal of Eco-Agriculture, 25, 520-529. [宗宁, 石培礼, 耿守保, 马维玲 (2017). 北方山区主要森林类 型树木叶片氮、磷回收效率研究. 中国生态农业学报, 25, 520-529.]

特邀编委: 黄建国 责任编辑: 李 敏 实习编辑: 赵 航 